\title{
Subterranean occurrence of Anaspides tasmaniae (Thomson) (Crustacea, Syncarida)
}

\author{
By W. D. Williamsin \\ With tspo figures in the text
}

Anaspides tasmaniae (Thom son) has been recorded from a variety of habitats in Tasmania, ranging from small moorland pools to upland lakes and streams. However, the usual habitat is small streams on or near the central Tasmanian plateau. The habitat distribution has been reviewed recently by Williams (in press). Despite the occurrence in Tasmania of several cave systems, the species has so far not been recorded from the subterranean habitat, although there is an obscure report of the occurrence of a single specimen in the stomach of a trout (Salmo fario Linne) caught in Kubla Khan cave in northern Tasmania (Scott 1960). The present paper records two subterranean occurrences, which, it is felt, are of particular interest on three counts. Firstly, they are the northern-most records for the species. Hitherto, the most northerly record of A.tasmaniae was that of Nicholls (1947) from the Cradle Mountain district. Secondly, they indicate that even within the phylogenetically relictual Anaspididae there is the tendency to lose pigmentation on the assumption of a subterranean habitat. And thirdly, they suggest that Anaspides is able to survive in the subterranean environment, an ability which may well have been of value during Tertiary periods of high temperature (Gill 1962), when caves perhaps functioned, together with the Tasmanian mountains and plateau, as oligothermal refuges.

The two records are based on samples collected by Mr. E. Hamilton-Smith (Melbourne) on 18 and 19 November, 1963, and now part of the collections of the South Australian Museum, Adelaide. The first sample (Registered Number B 5 0457) comprized three specimens, one a female of length (rostrum tip - telson tip) $24.2 \mathrm{~mm}$., the others two juveniles of lengths 7.3 and $8.7 \mathrm{~mm}$. This sample was collected from a small pool about 50 metres from the entrance to an unnamed cave

1) Department of Zoology and Comparative Physiology, Clayton, Victoria, Australia. 
situated near Sassafras Creek (Tasmanian State Aerial Survey Grid Reference, 320800). The pool contained clear water and had a mud bottom. The second sample (Registered Number B 5 0464) comprized five specimens, two females of length 30.1 and $38.4 \mathrm{~mm}$., two males of length 14.9 and $20.3 \mathrm{~mm}$., and one juvenile of length $8.8 \mathrm{~mm}$. This sample was collected from a small stream about 200 metres from the entrance to Marakoopa cave. Both caves lie in an area of Ordivician limestone (Banks 1962) in north-central Tasmania near Mole Creek. According to Banks (in Gill 1962), this area was not glaciated during the Pleistocene.

All specimens were examined carefully with particular regard to those characters which distinguish A.tasmaniae from the recently described species of Anaspides from Lake St. Clair (Williams in press), namely, the spinulation of the posterior margins of the third, fourth and fifth epimera, the dorsal and dorso-lateral margins of the fifth and sixth abdominal segments, the outer distal angle of the uropod peduncle and the posterior margin of the telson. In all these characters, the specimens were indistinguishable from A.tasmaniae. On the other hand, all the specimens quite clearly had much less pigment than is found in preserved specimens of A.tasmaniae from surface localities, as was indicated by a comparison with numerous specimens from eleven such localities. The three specimens from the cave near Sassafras Creek were completely without pigment in the preserved condition, and, according to Mr. Hamilton-Smith (personal communication), the same applied in live specimens. The five specimens from Marakoopa cave had some small patches of pigment, but nevertheless were paler than any surface specimen examined. Fig. 1 compares the largest of the specimens from Marakoopa cave with a surface specimen from a small stream near the Great Lake. As noted first by Manton (1930), A.tasmaniae tends to exhibit two colour varieties: one, a dark brown to olive green colour, the other a light brown colour. Nicholls (1947) suggested that the darker variety is the more prevalent. The surface specimen shown in Fig.1 belongs to the lighter variety.

In the two other respects in which subterranean forms commonly differ from their surface relatives, that is the reduction of eyes and attenuation of appendages, there was no difference between the specimens from the caves and surface forms of A.tasmaniae. Thus, all the cave specimens had prominent black eyes with no sign of any reduction, and none of the appendages showed any attenuation. The ratio of the length of the first antennae to the length of the body, for example, varied both above and below the values for this ratio in 
sixteen specimens of A.tasmaniae from a small moorland stream near the Great Lake. This can be seen from Fig. 2.

I am much indebted to Mr. E. Hamilton-Smith who passed on the two samples of cave specimens for my examination.

\section{SUMMARY}

1. Anaspides tasmaniae is recorded from a subterranean habitat for the first time.

2 . The only difference noted from surface forms was the smaller amount of pigment present.

\section{RÉSUMÉ}

1. Anaspides tasmaniae est signalé d'un habitat souterrain pour la première fois.

2. La seule différence remarquée avec les exemplaires de surface est une plus faible présence de pigments.
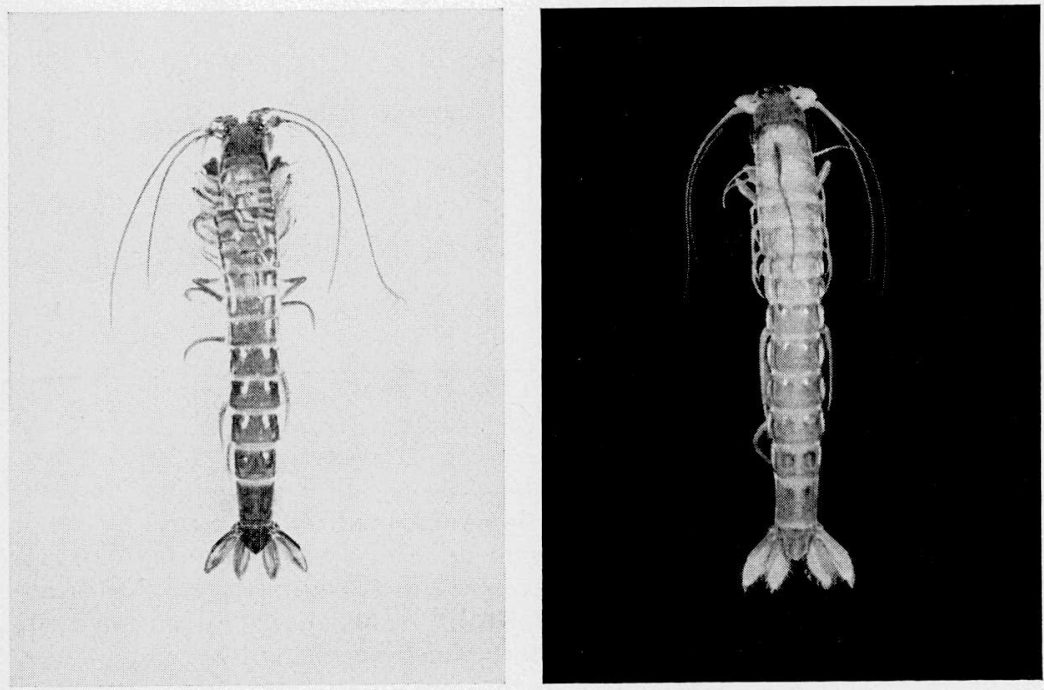

Fig. 1. Photograph comparing the degree of pigmentation in a surface specimen of the light brown colour variety of $A$. tasmaniae and in a specimen from Marakoopa cave. The left hand specimen is the surface form; the right hand specimen is the subterranean form. 


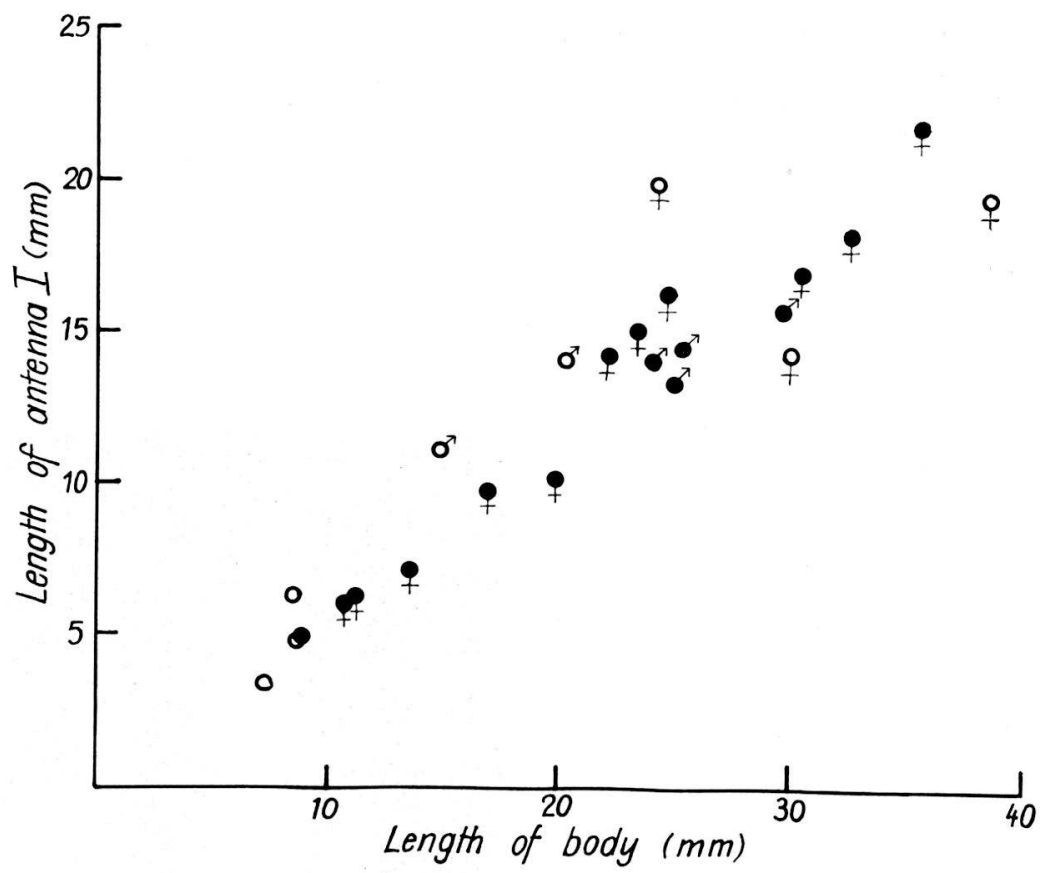

Fig. 2. Scatter diagram comparing the ratio of the length of the first antennae to the length of the body in the specimens from Sassafras Creek or Marakoopa caves and in sixteen specimens from a small moorland stream near the Great Lake. Circles indicate juveniles; subterranean forms are represented by empty ones, surface forms by solid ones. Conventional sex signs indicate adults; subterranean forms are represented by empty ones, surface forms by solid ones. 


\section{REFERENCES}

Banks, M. R. (1962) - The Ordivician System. Chapter 3 in: A. Spry \& Banks M. R. (Eds.), The Geology of Tasmania. Journ. Geol. Soc. Australia, 9 (2): 1-362. Adelaide.

Gill, E. D. (1962) - Cainozoic. Chapter 7 in: Ibid.

Manton, S. M. (1930) - Notes on the habits and feeding mechanisms of Anaspides and Paranaspides (Crustacea: Syncarida). Proc. zool. Soc. Lond. 1930: 791-800.

Nicholls, G. E. (1947) - On the Tasmanian Syncarida. Rec. Queen Vict. Mus. $2(1): 9-16$.

Scotт, E. O. G. (1960) - Introduced trout, Salmo fario Linne, 1758, from Kubla Khan Cave. Bulletin Tasmanian Caverneering Club, No. 4:9-18.

Williams, W. D. (in press). - Ecological notes on Tasmanian Syncarida (Crustacea: Malacostraca), with a description of a new species of Anaspides. Int. Revue ges. Hydrobiol. 50 (1). 